\title{
Alleviation of the two-cell block of ICR mouse embryos by polyaminocarboxylate metal chelators
}

\author{
T. Matsukawa, S. Ikeda, H. Imai and M. Yamada* \\ Laboratory of Reproductive Physiology, Graduate School of Agriculture, Kyoto University, \\ Kyoto 606-8502, Japan
}

The present study was undertaken to examine the effects of various transition metal ion chelators, both polyaminocarboxylates (including nitrilotriacetate (NTA), ethylenediaminediacetate (EDDA), ethyleneglycolbistetraacetate (EGTA), ethylenediaminetetraacetate (EDTA) and diethylenetriaminepentaacetate (DTPA)) and nonpolyaminocarboxylates (dipicolinic acid and deferoxamine), on the development in vitro of one-cell ICR strain mouse embryos to the four-cell and blastocyst stages. The order of stability constants of polyaminocarboxylates for transition metal ions such as zinc, copper and iron is as follows: NTA $\leqslant$ EDDA < EGTA < EDTA < DTPA. Addition of 10 or $100 \mu \mathrm{mol}$ polyaminocarboxylates $\mathrm{I}^{-1}$ to the medium significantly enhanced the development of most one-cell embryos $(66-88 \%)$ beyond the two-cell stage compared

\section{Introduction}

In vitro culture of one-cell embryos from most strains of mouse is known to result in developmental arrest during the G2 phase of the second cell cycle, when the major zygotic gene activation occurs. This developmental arrest is referred to widely as the 'two-cell block'. In some strains, such as the ICR strain, the developmental block is alleviated by adding ethylenediaminetetraacetate (EDTA) to the culture medium, resulting in an increased proportion of one-cell embryos that develop to the blastocyst stage (Abramczuk et al., 1977; Hoshi and Toyoda, 1985; Chatot et al., 1989; Lawitts and Biggers, 1992; Gardner and Lane, 1996). As EDTA is a cell membrane-impermeable metal ion chelator, the effects of EDTA may be exerted by chelating extracellular transition metal ions such as zinc, copper and iron. For example, chelation of transition metal ions by EDTA generally prevents the ions from participating in chemical reactions that generate harmful oxygen radicals (Halliwell and Gutteridge, 1984). Inclusion of superoxide dismutase (SOD) in culture medium without EDTA partially alleviates the two-cell block, although the effects of SOD are disputed and variable (Legge and Sellens, 1991; Noda et al., 1991; Payne et al., 1992; Johnson and Nasr-Esfahani, 1994). Thus, one possible role of EDTA in the culture medium is to act as

*Correspondence

Email:yamada@jkans.jkans.kais.kyoto-u.ac.jp with that $(<25 \%)$ in medium without polyaminocarboxylates. Although EDDA, EDTA and DTPA at $10 \mu \mathrm{mol} \mathrm{I}^{-1}$ induced the development of most one-cell embryos to the four-cell stage and beyond, a higher concentration $\left(100 \mu \mathrm{mol} \mathrm{I}^{-1}\right)$ of NTA and EGTA was required to obtain a similar result. Therefore, the ability of polyaminocarboxylates to overcome the two-cell block is not correlated with their potency to chelate transition metal ions. In contrast, the non-polyaminocarboxylates dipicolinic acid and deferoxamine, at 10 and $100 \mathrm{~mol} \mathrm{I}^{-1}$, did not have the same effect. Taken together, the results indicate that the ability of polyaminocarboxylates to overcome the two-cell block in embryo development is due to some common feature or features other than the ability to chelate transition metal ions. a chelator of transition metal ions to prevent extracellular generation of oxygen radicals. However, although polyaminocarboxylate metal chelators, including EDTA, nitrilotriacetate (NTA), ethylenediaminediacetate (EDDA), ethyleneglycolbistetraacetate (EGTA), and diethylenetriaminepentaacetate (DTPA), are commonly used to prevent metal-catalysed oxidation because they sequester metals, a number of studies have indicated that iron- or copperpolyaminocarboxylate complexes may be catalytically active as a result of their specific co-ordination geometry (Yamada et al., 1987; Stadtman, 1993; Asaumi et al., 1996; Okada, 1996; Zhao et al., 1996). Production of oxygen radicals, such as hydroxyl radicals, in the presence of polyaminocarboxylates tends to increase with decreased complex stability: NTA $\geqslant$ EDDA $\gg$ EDTA > DTPA (Asaumi et al., 1996; Okada, 1996; Zhao et al., 1996). Furthermore, it has been reported that iron-chelated EDTA (Fe-EDTA) plays a catalytic role and promotes the oxidation of amino acids by the classical Fenton system (Asaumi et al., 1996; Zhao et al., 1996). Moreover, although the metal ion complexes formed with EDTA and EGTA have similar stability constants, Hoshi and Toyoda (1985) reported that EGTA did not alleviate the two-cell block in embryo development. Thus, it remains unclear whether the alleviation effect of EDTA is mediated by its ability to chelate transition metal ions, resulting in either sequestration or generation of reactive oxygen radicals.

The aim of the present study was to examine the effects 
Table 1. Dose effects of ethylenediaminetetraacetate (EDTA) on development of one-cell ICR mouse embryos in vitro

\begin{tabular}{ccccc}
\hline \multirow{2}{*}{$\begin{array}{c}\text { EDTA } \\
\left(\mu \mathrm{mol} \mathrm{I}^{-1}\right)\end{array}$} & $\begin{array}{c}\text { Number of } \\
\text { embryos } \\
\text { examined }\end{array}$ & \multicolumn{3}{c}{ Percentage of embryos developed to } \\
\cline { 3 - 5 } & 47 & $100^{\mathrm{a}}$ & Four-cell stage & Blastocyst \\
\hline 0.0 & 50 & $100^{\mathrm{a}}$ & $24^{\mathrm{a}}$ & $3^{\mathrm{a}}$ \\
0.25 & 55 & $100^{\mathrm{a}}$ & $76^{\mathrm{b}}$ & $21^{\mathrm{ab}}$ \\
0.5 & 55 & $100^{\mathrm{a}}$ & $84^{\mathrm{c}}$ & $37^{\mathrm{b}}$ \\
1.0 & 56 & $100^{\mathrm{a}}$ & $92^{\mathrm{c}}$ & $59^{\mathrm{b}}$ \\
10 & 38 & $100^{\mathrm{a}}$ & $95^{\mathrm{c}}$ & $82^{\mathrm{c}}$ \\
100 & 53 & $100^{\mathrm{a}}$ & $64^{\mathrm{c}}$ & $85^{\mathrm{c}}$ \\
1000 & 53 & $3^{\mathrm{a}}$ \\
\hline
\end{tabular}

abc Values in the same column with different superscripts are significantly different.

of polyaminocarboxylates and other chelators (nonpolyaminocarboxylates) with different metal ion stability constants on the two-cell block in cultured ICR mouse embryos.

\section{Materials and Methods}

\section{Chemicals}

The chemicals used were obtained as follows: NTA, EDDA, EDTA, EGTA, DTPA, and $\mathrm{Ca}^{2+}$ - or $\mathrm{Mg}^{2+}$-saturated EDTA (Ca-EDTA and Mg-EDTA, respectively) from Dojindo Laboratories (Kumamoto); dipicolinic acid from Molecular Probes (Eugene, OR); and deferoxamine from Sigma (St Louis, MO).

\section{Embryo collection and culture}

Female ICR mice, aged 3-6 weeks, were superovulated by injection of 5 iu equine chorionic gonadotrophin (eCG) followed $48 \mathrm{~h}$ later by 5 iu human chorionic gonadotropin (hCG). The females were subsequently mated with male mice of the same strain, and vaginal plug formation was confirmed on the next morning (day 1). The female mice were anaesthetized with ether and killed by cervical dislocation. All procedures involving animals were approved by the Kyoto University Animal Care and Use Committee. Fertilized one-cell embryos were collected $20 \mathrm{~h}$ after administration of hCG from the ampullae of oviducts of superovulated females by tearing the ampullae with a hypodermic needle. After removal of cumulus cells by digestion with $0.1 \%(\mathrm{w} / \mathrm{v})$ hyaluronidase (Sigma) for approximately $5 \mathrm{~min}$, the embryos were placed in $50 \mu \mathrm{l}$ drops of culture medium, covered with mineral oil and cultured for 5 days at $37^{\circ} \mathrm{C}$ under $5 \% \mathrm{CO}_{2}$ in air. The embryos were observed every $24 \mathrm{~h}$ under a Nikon inverted microscope. The culture efficiency was evaluated by determining the proportion of embryos reaching the two-cell (day 2), four-cell (day 3) and blastocyst (day 5) stages.

The basal culture medium used was potassium simplex optimized medium (KSOM; Erbach et al., 1994) without
EDTA, supplemented with $0.1 \%(\mathrm{w} / \mathrm{v})$ polyvinylpyrrolidone instead of BSA and designated here as modified KSOM (mKSOM).

\section{Statistical analysis}

Each experiment was repeated three times. Subclass means were analysed by ANOVA and Scheffe's test. Percentage data were subjected to arcsine transformation before statistical analysis. A value of $P<0.05$ was considered to be an indication of significance.

\section{Results}

The first experiment examined the effects of EDTA at various concentrations on development in vitro of one-cell embryos at the pronuclear stage to the four-cell and blastocyst stages. When concentrations of EDTA $>0.25 \mu \mathrm{mol}$ $\mathrm{I}^{-1}$ were added to $\mathrm{mKSOM}$, the proportions of embryos reaching the four-cell and blastocyst stages increased significantly in a dose-dependent manner (Table 1). The prominent effects of EDTA on development to the four-cell and blastocyst stages were observed at concentrations of $0.5-100.0 \mu \mathrm{mol} \mathrm{I}^{-1}$ and $10-100 \mu \mathrm{mol} \mathrm{I}{ }^{-1}$, respectively (the rates of development to the four-cell and blastocyst stages were $75-92 \%$ and $80-82 \%$, respectively). However, ad-

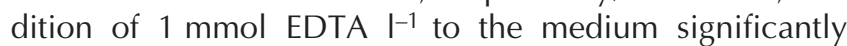
reduced the proportion of embryos that developed to the four-cell stage, and the resulting four-cell embryos did not develop to the blastocyst stage. In the control group, in which the embryos were cultured in mKSOM without EDTA, the developmental rates to the four-cell and blastocyst stages were $24 \%$ and $3 \%$, respectively.

Lane and Gardner (2001) suggested that the alleviation effect of EDTA is due to the chelation of divalent cations such as magnesium. Therefore, the next experiment examined the effects of Mg-EDTA and Ca-EDTA on development of one-cell embryos in vitro. Mg-EDTA and Ca-EDTA are non-magnesium and non-calcium chelators that are able to bind to metal ions with higher stability 
Table 2. Effects of $\mathrm{Ca}$ - and Mg-ethylenediaminetetraacetate (EDTA) on development of one-cell ICR mouse embryos in vitro

\begin{tabular}{lccccc}
\hline Additive & $\begin{array}{c}\text { Concentration } \\
\left(\mu \text { mol I-1 }^{-1}\right)\end{array}$ & $\begin{array}{c}\text { Number of } \\
\text { embryos } \\
\text { examined }\end{array}$ & Two-cell stage & Four-cell stage & Blastocyst \\
\cline { 5 - 6 }- & - & 65 & $100^{\mathrm{a}}$ & $14^{\mathrm{a}}$ & $0^{\mathrm{a}}$ \\
Ca-EDTA & 10 & 37 & $100^{\mathrm{a}}$ & $91^{\mathrm{b}}$ & $69^{\mathrm{b}}$ \\
& 100 & 40 & $100^{\mathrm{a}}$ & $89^{\mathrm{b}}$ & $73^{\mathrm{b}}$ \\
Mg-EDTA & 10 & 38 & $100^{\mathrm{a}}$ & $97^{\mathrm{b}}$ & $79^{\mathrm{b}}$ \\
& 100 & 38 & $100^{\mathrm{a}}$ & $98^{\mathrm{b}}$ & $74^{\mathrm{b}}$ \\
\hline
\end{tabular}

abc Values in the same column with different superscripts are significantly different.

Table 3. Stability constants of chelators for transition metal ions

\begin{tabular}{lccccc}
\hline & \multicolumn{5}{c}{ Log stability constant for } \\
\cline { 2 - 5 } Chelator & $\mathrm{Zn}^{2+}$ & $\mathrm{Cu}^{2+}$ & $\mathrm{Fe}^{3+}$ & $\mathrm{Ca}^{2+}$ & $\mathrm{Mg}^{2+}$ \\
\hline NTA $^{\mathrm{a}}$ & 10.7 & 13.0 & 15.9 & 6.4 & 5.5 \\
EDDA $^{\mathrm{a}}$ & 11.2 & 16.2 & 17.0 & $\mathrm{na}$ & 3.9 \\
EGTA $^{\mathrm{a}}$ & 14.5 & 17.8 & 20.5 & 11.0 & 5.2 \\
EDTA $^{\mathrm{a}}$ & 16.5 & 18.8 & 25.1 & 11.0 & 8.7 \\
DTPA $^{\mathrm{a}}$ & 18.8 & 21.5 & 28.6 & 10.7 & 9.3 \\
Dipicolinic acid $^{\mathrm{b}}$ & 6.4 & 9.1 & $\mathrm{na}$ & 4.4 & 2.3 \\
Deferoxamine $^{\mathrm{c}}$ & 11.1 & 14.1 & 30.6 & 2.6 & $\mathrm{na}$ \\
\hline
\end{tabular}

aData from Dojindo Laboratories, Kumamoto, Japan.

bData from Sakaguchi and Ueno (1967).

'Data from Imamura (1977).

DTPA: diethylenetriaminepentaacetate; EDDA: ethylenediaminediacetate; EDTA: ethylenediaminetetraacetate; EGTA: ethyleneglycolbistetraacetate; NTA: nitrilotriacetate; na: not available.

constants than magnesium and calcium ions, respectively.

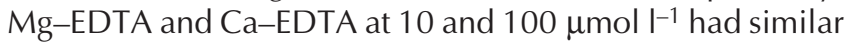
effects to 10 and $100 \mu \mathrm{mol}$ EDTA $\mathrm{I}^{-1}$ in alleviation of the two-cell block (Table 2). This result indicates that the effect of EDTA is not affected by the binding of magnesium or calcium ions to EDTA.

The ability of various polyaminocarboxylates (homologous ethyleneamine acetates) with different stability constants (Table 3) and non-polyaminocarboxylate chelators to alleviate the two-cell block was compared. All the polyaminocarboxylates examined had the ability to overcome the two-cell block (Table 4). Most embryos ( $\geqslant 95 \%$ ) treated with EDDA, EDTA or DTPA at 10 or $100 \mu \mathrm{mol}{ }^{-1}$ developed to the four-cell stage and subsequently to the blastocyst stage. However, in the embryos treated with NTA or EGTA at $10 \mu \mathrm{mol}{ }^{-1}$, no significant increase in the proportions of embryos at the four-cell and blastocyst stages was observed compared with embryos cultured in the basal medium. However, both NTA and EGTA at $100 \mu \mathrm{mol} \mathrm{I}^{-1}$ alleviated the two-cell block. The proportion of embryos reaching the four-cell stage was significantly lower in the EGTA-treated embryos $(66 \%)$, but not in the NTA-treated embryos $(88 \%)$, than in embryos treated with other polyaminocarboxylates $(\geqslant 95 \%)$. The rates of development to the blastocyst stage of embryos treated with NTA or EGTA at $100 \mu \mathrm{mol} \mathrm{I}^{-1}$ (74\% and 48\%, respectively) were also lower compared with those $(\geqslant 89 \%)$ of embryos treated with other polyaminocarboxylates.

The effects of dipicolinic acid and deferoxamine, nonpolyaminocarboxylates, on the development of one-cell embryos are summarized (Table 5). Dipicolinic acid has a lower stability constant for zinc, copper and iron than any of the polyaminocarboxylates (Table 3), but is generally used as a selective zinc chelator (Yamaguchi and Matsui, 1989; Larson and Kitto, 1999). Deferoxamine has a similar stability constant to EDDA for zinc and copper, but has the highest stability constant for iron among the chelators examined, and is generally used as a selective iron chelator (Nasr-Esfahani et al., 1990). In embryos treated with 10 and $100 \mu \mathrm{mol}$ dipicolinic acid $\mathrm{I}^{-1}$, the rates of development to the four-cell ( $6 \%$ and $27 \%$, respectively) and blastocyst $(0 \%$ and $3 \%$, respectively) stages were not significantly different from those in the untreated control embryos (four-cell stage embryos, 6\% and blastocysts, $0 \%$ ). However, when onecell embryos were treated with 1 or $10 \mu \mathrm{mol}$ deferoxamine $\mathrm{I}^{-1}$, the cleavage rates (73\% and 53\%, respectively) to the twocell stage were significantly lower than those (100\%) of the control embryos; moreover, deferoxamine did not overcome 
Table 4. Effects of polyaminocarboxylates on development of one-cell ICR mouse embryos in vitro

\begin{tabular}{|c|c|c|c|c|c|}
\hline \multirow[b]{2}{*}{ Additive } & \multirow{2}{*}{$\begin{array}{c}\text { Concentration } \\
\left(\mu \mathrm{mol} \mathrm{I}^{-1}\right)\end{array}$} & \multirow{2}{*}{$\begin{array}{l}\text { Number of } \\
\text { embryos } \\
\text { examined }\end{array}$} & \multicolumn{3}{|c|}{ Percentage of embryos developed to } \\
\hline & & & Two-cell stage & Four-cell stage & Blastocyst \\
\hline- & - & 50 & $100^{\mathrm{a}}$ & $0^{\mathrm{a}}$ & $0^{\mathrm{a}}$ \\
\hline \multirow[t]{2}{*}{ NTA } & 10 & 52 & $100^{a}$ & $22^{\mathrm{a}}$ & $2^{\mathrm{a}}$ \\
\hline & 100 & 53 & $100^{\mathrm{a}}$ & $88^{\mathrm{b}}$ & $74^{\mathrm{b}}$ \\
\hline \multirow[t]{2}{*}{ EDDA } & 10 & 52 & $100^{\mathrm{a}}$ & $98^{\mathrm{b}}$ & $97^{b}$ \\
\hline & 100 & 51 & $100^{a}$ & $98^{b}$ & $96^{\mathrm{b}}$ \\
\hline \multirow[t]{2}{*}{ EGTA } & 10 & 50 & $100^{a}$ & $4^{\mathrm{a}}$ & $0^{\mathrm{a}}$ \\
\hline & 100 & 52 & $100^{\mathrm{a}}$ & $66^{c}$ & $48^{\mathrm{c}}$ \\
\hline \multirow[t]{2}{*}{ EDTA } & 10 & 51 & $100^{a}$ & $95^{\mathrm{b}}$ & $89^{b}$ \\
\hline & 100 & 52 & $100^{\mathrm{a}}$ & $98^{b}$ & $98^{b}$ \\
\hline \multirow[t]{2}{*}{ DTPA } & 10 & 52 & $100^{\mathrm{a}}$ & $100^{b}$ & $97^{b}$ \\
\hline & 100 & 51 & $100^{\mathrm{a}}$ & $98^{b}$ & $96^{b}$ \\
\hline
\end{tabular}

DTPA: diethylenetriaminepentaacetate; EDDA: ethylenediaminediacetate; EDTA: ethylenediaminetetraacetate; EGTA: ethyleneglycolbistetraacetate; NTA: nitrilotriacetate.

abcValues in the same column with different superscripts are significantly different.

Table 5. Effects of dipicolinic acid and deferoxamine on development of one-cell ICR mouse embryos in vitro

\begin{tabular}{|c|c|c|c|c|c|}
\hline \multirow[b]{2}{*}{ Additive } & \multirow{2}{*}{$\begin{array}{l}\text { Concentration } \\
\left.\qquad(\mu \mathrm{mol} \mathrm{I})^{-1}\right)\end{array}$} & \multirow{2}{*}{$\begin{array}{l}\text { Number } \\
\text { of embryos } \\
\text { examined }\end{array}$} & \multicolumn{3}{|c|}{ Percentage of embryos developed to } \\
\hline & & & Two-cell stage & Four-cell stage & Blastocyst \\
\hline- & - & 105 & $100^{\mathrm{a}}$ & $6^{\mathrm{a}}$ & $0^{\mathrm{a}}$ \\
\hline \multirow[t]{2}{*}{ Dipicolinic acid } & 10 & 62 & $100^{\mathrm{a}}$ & $6^{\mathrm{a}}$ & $0^{\mathrm{a}}$ \\
\hline & 100 & 64 & $100^{\mathrm{a}}$ & $27^{\mathrm{a}}$ & $3^{\mathrm{a}}$ \\
\hline \multirow[t]{2}{*}{ Deferoxamine } & 1 & 48 & $73^{b}$ & $7^{a}$ & $0^{\mathrm{a}}$ \\
\hline & 10 & 49 & $53^{b}$ & $0^{\mathrm{a}}$ & $0^{\mathrm{a}}$ \\
\hline
\end{tabular}

abValues in the same column with different superscripts are significantly different.

the two-cell block at either concentration. Thus, deferoxamine, at the concentrations examined, is deleterious to embryo development during the early cleavage stages.

When one-cell embryos were cultured in medium supplemented with both deferoxamine and EDTA, each at $10 \mu \mathrm{mol} \mathrm{I-1}$ (Table 6), almost the same proportion of embryos developed to the four-cell stage as when the embryos were treated with $10 \mu \mathrm{mol}$ EDTA I-1 alone. However, development to the blastocyst stage was completely inhibited in embryos treated with both chelators. These results indicate that the effect of EDTA on the two-cell block is exerted in a different way from the effect of deferoxamine.

\section{Discussion}

The present study showed that polyaminocarboxylates with various metal ion stability constants, including NTA, EDDA, EGTA, EDTA and DTPA, had the ability to overcome the two-cell block in development of ICR mouse embryos, whereas dipicolinic acid and deferoxamine, which are nonpolyaminocarboxylate metal ion chelators, did not. EDTA caused maximum alleviation of the two-cell block at
$10 \mu \mathrm{mol} \mathrm{I}^{-1}$. At $10 \mu \mathrm{mol} \mathrm{I}^{-1}$, EDDA and DTPA, weak and strong chelators, respectively, compared with EDTA, had a similar ability to $10 \mu \mathrm{mol} \mathrm{EDTA} \mathrm{I}^{-1}$ to overcome the two-cell block. Although NTA, like EDDA, is a weak chelator, and EGTA has a similar stability constant to EDTA, a higher concentration $\left(100 \mu \mathrm{mol} \mathrm{I}^{-1}\right)$ of both NTA and EGTA was required to produce a significant increase in the proportion of embryos developing beyond the two-cell stage. This finding indicates that the ability of polyaminocarboxylates to overcome the two-cell block is not correlated with their potency to chelate transition metal ions. Moreover, it was found that deferoxamine at 1 and $10 \mu \mathrm{mol} \mathrm{I}^{-1}$ inhibited the first cleavage division of the embryos. As the stability constant of deferoxamine for iron is much greater than that of the other chelators examined in the present study, the adverse effect may be caused by chelation of an excess amount of iron in the extracellular pool (Nasr-Esfahani et al., 1990). The adverse effect of deferoxamine was almost completely rescued by adding EDTA to deferoxaminecontaining medium; furthermore, EDTA was able to promote the development of the embryos to the four-cell stage in deferoxamine-containing medium. As deferox- 
Table 6. Effects of combined addition of deferoxamine and ethylenediaminetetraacetate (EDTA) on development of one-cell ICR mouse embryos in vitro

\begin{tabular}{|c|c|c|c|c|}
\hline \multirow[b]{2}{*}{ Additive } & \multirow{2}{*}{$\begin{array}{c}\text { Number of } \\
\text { embryos } \\
\text { examined }\end{array}$} & \multicolumn{3}{|c|}{ Percentage of embryos developed to } \\
\hline & & Two-cell stage & Four-cell stage & Blastocyst \\
\hline- & 44 & $100^{\mathrm{a}}$ & $5^{\mathrm{a}}$ & $0^{\mathrm{a}}$ \\
\hline $\operatorname{EDTA}(10 \mu \mathrm{mol} \mathrm{I-1})$ & 62 & $100^{\mathrm{a}}$ & $94^{\mathrm{b}}$ & $72^{b}$ \\
\hline Deferoxamine $\left(10 \mu \mathrm{mol} \mathrm{I}^{-1}\right)$ & 49 & $53^{b}$ & $0^{\mathrm{a}}$ & $0^{\mathrm{a}}$ \\
\hline $\begin{array}{l}\text { EDTA }\left(10 \mu \mathrm{mol} \mathrm{I}^{-1}\right)+\text { deferoxamine } \\
\left(10 \mu \mathrm{mol} \mathrm{^{-1 } )}\right.\end{array}$ & 50 & $98^{\mathrm{a}}$ & $83^{b}$ & $0^{\mathrm{a}}$ \\
\hline
\end{tabular}

${ }^{a b}$ Values in the same column with different superscripts are significantly different.

amine and EDTA are both transition metal ion chelators, the results of this experiment indicate that the effect of EDTA on early embryos is exerted via a mechanism other than the chelation of iron.

In a study of one-cell ICR mouse embryos produced by in vitro fertilization, Hoshi and Toyoda (1985) reported that, unlike EDTA, EGTA $\left(100 \mu \mathrm{mol} \mathrm{I}^{-1}\right)$ had no ability to promote development of the embryos in vitro beyond the two-cell stage, which is inconsistent with the results of the present study. It is possible that this discrepancy is the result of differences between the developmental potential of pronuclear stage one-cell embryos produced by fertilization in vivo and in vitro. Although the two-cell block of in vitro fertilized AKR/N mouse embryos cultured in phosphatecontaining medium ( $\geqslant 1 \mu \mathrm{mol} \mathrm{l^{-1 }}$ ) was not alleviated by the addition of EDTA (Haraguchi et al., 1996), the developmental arrest at the two-cell stage of in vivo fertilized AKR/N pronuclear stage embryos could be alleviated by the addition of $10 \mu \mathrm{mol}$ EDTA ${ }^{-1}$, even in phosphate-containing medium (T. Matsukawa, S. Ikeda and M. Yamada, unpublished).

Polyaminocarboxylates are generally believed to be cell membrane-impermeable chelators as they are negatively charged, which prevents their intracellular transport. Therefore, the various biological effects of polyaminocarboxylates are thought to be exerted extracellularly (Morimoto et al., 1992; Chattopadhyay and Freake, 1998; Lefebvre et al., 1998; Sciaudine et al., 2000). If exogenous polyaminocarboxylates could be incorporated into early mouse embryos through endocytosis, they should be capable of acting intracellularly. However, early cleavage-stage mouse embryos lack effective endocytotic capacity (Nasr-Esfahani and Johnson, 1992). Moreover, when NTA and EDDA chelate metal ions, they form uncharged complexes that are able to penetrate the membrane and may also act inside the cell (Kachur et al., 1998). However, as the effect of EDDA on alleviation of the two-cell block was similar to that of EDTA and DTPA, which are unable to penetrate the membrane of embryos, it is likely that the effect was predominantly the result of the extracellular action of polyaminocarboxylates. In preliminary experiments using microinjection of EDTA into either the cytoplasm or the perivitelline space of one-cell embryos, normal develop- ment beyond the two-cell stage was observed only in embryos that received EDTA in the perivitelline space (Fissore et al., 1989). The results of these experiments indicate that the alleviation effects of polyaminocarboxylates are exerted at or outside the vitelline membrane of the embryo. This contention is in agreement with the suggestion of Abramczuk et al. (1977) that EDTA may act on the cell surface of embryos. The results of the present study combined with these earlier findings indicate that the beneficial effects are not due to extracellular chelation of transition metal ions by polyaminocarboxylates and the consequent reduction of oxidative stress.

Treatment of early embryos at the cleavage stages with EDTA regulates their glycolytic metabolism, resulting in the suppression of the high glycolytic activity induced by abnormal utilization of glucose in culture (Gardner and Lane, 1993). The excess utilization of glucose by embryos at early cleavage stages has been implicated in the induction of embryonic arrest in culture (Barbehenn et al., 1974; Chatot et al., 1989; Brown and Whittingham, 1991, 1992; Martin and Leese, 1995), which appears to be mediated by the Crabtree effect, inhibition of respiration and oxidative phosphorylation by glucose (Crabtree, 1929; Seshagiri and Bavister, 1971). Moreover, it appears that the mechanism of suppression of the high glycolytic activity of early cleavage stage embryos by EDTA is due to the inhibition of cytosolic kinases involved in the glycolytic pathway (Lane and Gardner, 1997). Lane and Gardner (2001) reported that the two-cell block in CF1 mouse zygotes was overcome by treatment with Cibacron blue, an inhibitor of 3-phosphoglycerate kinase (3-PGK), which is a key enzyme in glycolysis, and that 3-PGK activity in $\mathrm{F}_{1}(\mathrm{C} 57 \mathrm{BL} / 6 \times$ $\mathrm{CBA} / \mathrm{Ca}$ ) hybrid mouse zygotes, which have no characteristic features of developmental block at the two-cell stage, was reduced by EDTA treatment. They also found that the intracellular content of magnesium ions, which are a cofactor of 3-PGK, was reduced by EDTA treatment in $F_{1}$ hybrid mouse embryos. Therefore, it was suggested that alleviation of the two-cell block in CF1 mouse zygotes by EDTA treatment is due to intracellular chelation of magnesium ions, causing a reduction in 3-PGK activity. However, in the present study, although NTA and EGTA 
have much higher stability constants for magnesium ion than does EDDA (see Table 3), higher concentrations of NTA and EGTA than of EDDA were required to alleviate the two-cell block of ICR mouse embryos. Furthermore, Mg-EDTA, a non-magnesium ion chelator, at 10 or $100 \mu \mathrm{mol} \mathrm{I-1}$, alleviated the two-cell block in ICR mouse embryos to a similar extent as did EDTA.

The present study demonstrated that polyaminocarboxylates with different stability constants for transition metal ions have an ability to alleviate the two-cell block in ICR mouse zygotes; however, this ability was not necessarily correlated with the stability constants of the polyaminocarboxylates. Accordingly, although it remains to be clarified how EDTA and other polyaminocarboxylates alleviate the two-cell block in ICR mouse embryos, it seems likely that some common structural feature of polyaminocarboxylates, other than their ability to chelate metal ions, is required to promote embryonic development, especially beyond the second cell cycle division.

This work was supported in part by Grants-in-Aid for Scientific Research from the Ministry of Education, Culture, Sports, Science and Technology, Japan, and from the Association of Livestock Technology (Japan).

\section{References}

Abramczuk J, Solter D and Koprowski H (1977) The beneficial effects of EDTA on development of mouse one-cell embryos in chemically defined medium Developmental Biology 61 378-383

Asaumi A, Ogino T, Akiyama T, Kawabata T and Okada S (1996) Oxidative damages by iron-chelate complexes depend on the interaction with the target molecules Biochemistry and Molecular Biology International 39 $77-86$

Barbehenn EK, Wales RG and Lowry OH (1974) The explanation for the blockade of glycolysis in early mouse embryos Proceedings National Academy of Sciences USA 71 1056-1060

Brown JJG and Whittingham DG (1991) The roles of pyruvate, lactate and glucose during preimplantation development of embryos from $F_{1}$ hybrid mice in vitro. Development 112 99-105

Brown JJG and Whittingham DG (1992) The dynamic provision of different energy substrates improves development of one-cell random bred embryos in vitro. Journal of Reproduction and Fertility 95 503-511

Chatot CL, Ziomek CA, Bavister BD, Lewis JL and Torres I (1989) An improved culture medium supports development of random-bred 1-cell mouse embryos in vitro. Journal of Reproduction and Fertility $\mathbf{8 6}$ 679-688

Chattopadhyay S and Freake HC (1998) Zinc chelation enhances thyroid hormone induction of growth hormone mRNA in GH3 cells Molecular and Cellular Endocrinology 136 151-157

Crabtree HG (1929) Observations on the carbohydrate metabolism of tumors Biochemical Journal 23 536-545

Erbach GT, Lawitts JA, Papaioannou VE and Biggers JD (1994) Differential growth of the mouse preimplantation embryo in chemically defined media Biology of Reproduction 50 1027-1033

Fissore RA, Jackson KV and Kiessling AA (1989) Mouse zygote development in culture medium without protein in the presence of ethylenediaminetetraacetic acid Biology of Reproduction 41 835-841

Gardner DK and Lane M (1993) The 2-cell block in CF1 mouse embryos is associated with an increase in glycolysis and a decrease in tricarboxylic acid (TCA) cycle activity: alleviation of the 2-cell block is associated with the restoration of in vivo metabolic pathway activities Biology of Reproduction $\mathbf{4 8}$ Supplement 196

Gardner DK and Lane M (1996) Alleviation of the '2-cell block' and development to the blastocyst of CF1 mouse embryos: role of amino acids, EDTA and physical parameters Human Reproduction 11 2703-2712

Halliwell G and Gutteridge JMC (1984) Oxygen toxicity, oxygen radicals, transition metals and disease Biochemical Journal 219 1-14

Haraguchi S, Naito K, Azuma S, Sato E, Nagahama Y, Yamashita M and Toyoda Y (1996) Effects of phosphate on in vitro 2-cell block of AKR/N mouse embryos based on changes in cdc2 kinase activity and phosphorylation states Biology of Reproduction 55 598-603

Hoshi M and Toyoda Y (1985) Effect of EDTA on the preimplantation development of mouse embryos in vitro. Japanese Journal of Zootechnical Science $\mathbf{5 6}$ 931-937

Imamura S (1977) Application of complexan and its derivatives. In EDTA Chemistry of Complexan pp 121-226 Ed. K Ueno. Nankodo Co Ltd, Tokyo

Johnson MH and Nasr-Esfahani MH (1994) Radical solutions and cultural problems: could free oxygen radicals be responsible for the impaired development of preimplantation mammalian embryos in vitro? BioEssays 16 31-38

Kachur AV, Tuttle SW and Biaglow JE (1998) Autoxidation of ferrous ion complexes: a method for the generation of hydroxyl radicals Radiation Research 150 475-482

Lane M and Gardner DK (1997) EDTA stimulates development of cleavage stage mouse embryos by inhibiting the glycolytic enzyme 3phosphoglycerate kinase Biology of Reproduction 57 Supplement 1131

Lane M and Gardner DK (2001) Inhibiting 3-phosphoglycerate kinase by EDTA stimulates the development of the cleavage stage mouse embryo Molecular Reproduction and Development 60 233-240

Larson AA and Kitto K (1999) Chelation of zinc in the extracellular area of the spinal cord, using ethylenediaminetetraacetic acid disodiumcalcium salt or dipicolinic acid, inhibits the antinociceptive effect of capsaicin in adult mice Journal of Pharmacology and Experimental Therapeutics 288 759-765

Lawitts JA and Biggers JD (1992) Joint effects of sodium chloride, glutamine and glucose in mouse preimplantation embryo culture media Molecular Reproduction and Development 31 189-194

Lefebvre D, Beckers F, Ketelslegers JM and Thissen JP (1998) Zinc regulation of insulin-like growth factor-I (IGF-I), growth hormone receptor $(\mathrm{GHR})$ and binding protein $(\mathrm{GHBP})$ gene expression in rat cultured hepatocytes Molecular and Cellular Endocrinology 138 127-136

Legge $\mathbf{M}$ and Sellens MH (1991) Free radical scavengers ameliorate the 2-cell block in mouse embryo culture Human Reproduction 6 867-871

Martin KL and Leese HJ (1995) Role of glucose in mouse preimplantation embryo development Molecular Reproduction and Development $\mathbf{4 0}$ 436-443

Morimoto S, Shiraishi T, Fukuo K, Koh E, Kitano S, Yasuda O, Tamatani M and Ogihara T (1992) EDTA induces differentiation and suppresses proliferation of promyelocytic leukemia cell line HL-60 - possible participation of zinc Biochemistry International 28 313-321

Nasr-Esfahani MH and Johnson MH (1992) How does transferrin overcome the in vitro block to development of the mouse preimplantation embryo? Journal of Reproduction and Fertility 96 41-48

Nasr-Esfahani M, Johnson MH and Aitken RJ (1990) The effect of iron and iron chelators on the in vitro block to development of the mouse preimplantation embryo: BAT6 a new medium for improved culture of mouse embryos in vitro. Human Reproduction 5 997-1003

Noda Y, Matsumoto H, Umaoka Y, Tatsumi K, Kishi J and Mori T (1991) Involvement of superoxide radicals in the mouse two-cell block Molecular Reproduction and Development 28 356-360

Okada S (1996) Iron-induced tissue damage and cancer. The role of reactive oxygen species-free radicals Pathology International 46 311-332

Payne SR, Munday R and Thompson JG (1992) Addition of superoxide dismutase and catalase does not necessarily overcome developmental retardation of one-cell mouse embryos during in vitro culture Reproduction, Fertility and Development 4 167-174

Sakaguchi S and Ueno K (1967) Appendix. In Metal Chelate (III) pp 1-78. Nankodo Co Ltd, Tokyo

Sciaudone MP, Chattopadhay S and Freake HC (2000) Chelation of zinc amplifies induction of growth hormone mRNA levels in cultured rat pituitary tumor cells Journal of Nutrition 130 158-163 
Seshagiri PB and Bavister BD (1991) Glucose and phosphate inhibit respiration and oxidative metabolism in cultured hamster eight-cell embryos: evidence for the 'Crabtree effect' Molecular Reproduction and Development 30 105-111

Stadtman ER (1993) Oxidation of free amino acids and amino acid residues in proteins by radiolysis and by metal-catalyzed reactions Annual Review of Biochemistry 62 797-821

Yamada M, Okigaki T and Awai M (1987) Role of superoxide radicals in cytotoxic effects of Fe-NTA on cultured normal liver epithelial cells Cell Structure and Function 12 407-420

Yamaguchi M and Matsui R (1989) Effect of dipicolinate, a chelator of zinc, on bone protein synthesis in tissue culture. The essential role of zinc Biochemical Pharmacology 38 4485-4489

Zhao F, Yang J and Schoneich C (1996) Effects of polyaminocarboxylate metal chelators on iron-thiolate induced oxidation of methionine- and histidine-containing peptides Pharmaceutical Research 13 931-938

Received 6 December 2001

First decision 25 January 2002.

Accepted 27 February 2002. 